\title{
IV
}

\section{A EDUCAÇÃO POPULAR E AS RADICALIDADES HISTÓRICAS NA AMÉRICA LATINA*}

La educación popular tiene que reconocerse como un proyecto necesariamente inacabado en los marcos de la sociedad no transformada o en vias de transformación en que se piensa y actúa, como una educación de y para hombres y mujeres nuevos que se construyen a si mismos en el proceso de construir una nueva sociedad. Ello supone una creencia radical en la capacidad de autotransformación de los sujetos, una apertura también radical a las enseñanzas de la práctica social y también la asunción de ciertos elementos de método que demuestren su utilidad para superar las intencionalidades de sujeción incrustadas en las prácticas educativas vigentes (PEREZ, E. 2016, Grifo nosso)

Cristiane Sabino de Soura ${ }^{1}$
Roberta Traspadini ${ }^{2}$

\section{INTRODUÇÃO}

Este capítulo tem por objetivo tratar a educação popular como brecha/fonte/revanche histórica, em meio ao modelo de desenvolvimento excludente e desigual, consolidado como espaço-tempo de fraturas e feituras; de contrastes e contradições ao longo do século XX. A exclusão da maioria, inerente ao projeto de desenvolvimento da Nação de poucos à custa do trabalho superexplorado de muitos(as), reflete-se no sistema educacional, que, para existir, dentro da lógica da propriedade privada, deixa de fora ampla parcela da clas-

${ }^{*}$ DOI - 10.29388/978-65-86678-35-2-0-f.97-128

${ }^{1}$ Doutora em Serviço Social. Professora do Departamento de Serviço Social da Universidade Federal de Santa Catarina. Educadora Popular. Membro do Instituto de Estudos Latinoamericanos (IELA/UFSC). E-mail: crisabino1@gmail.com

${ }^{2}$ Doutora em Educação. Professora do curso de Relações Internacionais e Integração (UNILA) e dos programas de Pós Graduação em Relações Internacionais (UNILA), Serviço Social (UFSC). Coordenadora do Observatório de Educação Popular e Movimentos Sociais na América Latina (UFES-UNILA); e do Grupo de Pesquisa Saberes em movimento na luta por terra e trabalho na América Latina (UNILA). E-mail: robertatraspadini@gmail.com 
se trabalhadora - em particular, negros/as, pobres, camponeses/as e indígenas.

A educação pública brasileira segue as trilhas do capitalismo dependente (MARINI, 2011), sob atuação rigorosa de um Estado nacional burguês na particularidade da América Latina (CUEVA, 1983), cuja atuação de classe - burguesa - se reveste de antidemocracia, autoritarismo, subserviência aos projetos imperialistas-colonialistas, além do controle e repressão das demandas populares. É literalmente um Estado de coerção e consenso sem pausas na repressão para os/as que vivem e lutam por acessar o tão propalado universo do Estado de direito.

Sob este caráter - Estado oligárquico dependente - próprio da condição estrutural latino-americana, se consolida um modelo formal-institucional de educação que restringe o popular à mera reprodução histórica da desigualdade econômica, política, social e cultural. É desse popular que não cabe dentro da ordem a não ser com o estigma dos/das "ninguéns", que sofrerão todo tipo de estereotipação de uma condição à margem - não por opção, mas por falta de -, que a educação popular se forja e é forjada. Suas raízes profundas, abrem alas à produção, no presente, de uma recuperação histórica em que a memória entoa a cultura, a arte, o saber popular como revanches.

Entendemos - nas premissas da teoria marxista da dependência ${ }^{3}$ - que recuperar a trajetória histórica da educação, bem como suas formas recentes, no século XXI (e entender as disputas e contradições que a permeiam entre uma aparente democratização e o funil que demarca a sua real concretização), requer situá-la no processo metabólico particular da engrenagem da superexploração da força de trabalho, em sua dinâmica de produção e reprodução interna e externa do capital (MARINI, 2011; TRASPADINI, 2018; AMARAL, 2014). Exige, pois, não perder de vista a centralidade, na vida cotidiana da classe trabalhadora, das raízes históricas demarcadoras da presença colonial reiterada pelo imperialismo, através de suas estratégias coercitivas e consensuais contínuas de dominação (FERNANDES, 1983). Processo este, que reforça a manutenção e expansão do poder de uma classe (capitalista) sobre outra (trabalhadora) ao longo da história do desenvolvimento dependente, sob o qual o sistema educacional

\footnotetext{
${ }^{3}$ Para uma aproximação ao tema da Teoria Marxista da Dependência ver: AMARAL, M. Verbete superexploração. In: MARINI, R. M. A dialética da dependência. São Paulo: Editora expressão popular. Documentário, 2014.
} 
exerce papel fundamental para a propagação ideológica das supostas verdades burguesas.

Neste artigo, ao recuperarmos a trajetória de lutas pela educação, dos/ das dominados(das) e superexplorados(as), buscamos explicitar a constituição da educação popular como fruto da práxis dos sujeitos políticos (na diversidade de formas, tempos e processos de organização social da resistência que tal tema implica, na realidade latino-americana) (JARA, 2020)

Além dessa introdução, trabalharemos três pontos conectados: 1) uma reflexão sobre o sentido da educação no capitalismo dependente; 2) um breve apontamento acerca do sentido da educação popular na América Latina; 3) algumas experiências de educação popular no Brasil do século XX e XXI. Na articulação entre eles, pretendemos demarcar, ao final, como a educação popular, articulada à luta dos/das dominados/das e superexplorados(das) - movimentos negros, camponeses, indígenas -, constitui-se em revanche histórica, manifesta na insubordinação, resistência e construção de alternativas à miséria materialespiritual da sociedade burguesa em geral, e do capitalismo dependente, em particular.

\section{RETRATO DA EDUCAÇÃO FORMAL NO CAPITALISMO DE- PENDENTE CONTEMPORÂNEO}

É na dinâmica do imperialismo e da dependência (DOS SANTOS, 1978), ao longo do século XX, e em suas diferentes fases de articulação dialética - entre os capitais transnacionais-financeiros e a oligarquia agrária e burguesia industrial nacionais -, que devemos buscar as pistas históricas das nossas atrofias sociais referentes à estrutura e à cultura educacional brasileiras. Educação e trabalho são indissociáveis na história do desenvolvimento brasileiro (FRIGOTTO; CIAVATTA, 2016). No século XXI, quanto maior o fosso entre emprego formal-informal-desemprego, tanto maiores os dilemas vividos no ambiente escolar no que tange à evasão, distorção ano-série, baixo tempo de escolaridade regular. A realidade brasileira do mundo do trabalho evidencia a força do emprego informal sobre o formal e, neste, a precarização do trabalho 
como gênese e tendência ${ }^{4}$. Segundo o IBGE (2020), são 12,8 milhões de pessoas desempregadas; 24 milhões desistiram de procurar emprego, e 27 milhões atuam por conta própria. No âmbito formal são quase 95 milhões de trabalhadores/as, com uma média salarial $\mathrm{R} \$ 2.300,00$; sendo que os trabalhadores informais ou por conta própria ganham $40 \%$ a menos, em média. Isto, se comparado ao estudo de agosto do DIEESE (2020), sobre o mínimo necessário para sobreviver com dignidade no Brasil atual - $\mathrm{R} \$ 4.536,00$-, expõe a manutenção das Veias Abertas (GALEANO, 1971). Aliada a essa condição estrutural do desemprego-precarização está o alto número de pessoas que não sabem ler e escrever: quase 11 milhões. Além disso, 30\% da população é considerada como analfabeta funcional, isto é, leem e escrevem, mas não conseguem interpretar (INSTITUTO PAULO MONTENEGRO, 2018).

O movimento contínuo do desenvolvimento desigual e combinado no Brasil, palco do capitalismo dependente e da superexploração, aponta para uma educação distante, no século XXI, do próprio sentido do trabalho que a baliza. Uma escola e uma realidade cindidos. À precarização do trabalho se soma a precarização da educação como direito social com qualidade no sentido público da ação (ARROYO, 2007).

Em 1977, Ruy Mauro Marini e Paulo Speller escreveram um texto sobre A Universidade brasileira. Os autores destacam que, no plano da dominação burguesa, a universidade cumpre três funções: 1) reprodução ideológica da condição de classe dominante; 2) conformação da ciência e da técnica para a manutenção e expansão do capital; 3) aliança de classes efetivada pela burguesia nacional, industrial-comercial, frente às históricas heranças do poder da burguesia agrária-oligárquica (MARINI; SPELLER, 1977). Em uma abordagem ancorada na formação social e histórica do Brasil colonial e sua herança escravocrata, os autores explicitam como, no fetiche manipulador da separação entre o trabalho intelectual e o trabalho manual, presentes em uma sociedade que segregou a população alforriada à condição de sem-terra, sem-letras, sem-moradias e semtrabalho, a educação superior vai, ao longo do tempo, tornando-se em mera matriz ideo-política do capital (inter)nacional. Nas palavras dos autores:

\footnotetext{
"Sugerimos o documentário brasileiro, "GIG: a uberização do trabalho", sob a direção de Carlos Juliano Barros, Caue Angeli, Maurício Monteiro Filho, 2019.
} 
A escravidão leva a separação entre o trabalho manual e o intelectual ao seu limite extremo. O trabalho manual é considerado não apenas como algo desagradável, mas também degradante, sinal visível do status de sujeição. A formação educativa das camadas médias e superiores se distancia, então, até onde é possível, de tudo que tenha relação com a produção material. Onde o trabalho produtivo é identificado como sujeição e degradação, a cultura se cristaliza em outro polo como refinamento e excelência. Assim, a educação superior não tem como desenvolver as três funções que a caracterizam, no marco da sociedade burguesa, e aparece, mutilada e caricaturizada, reduzida à sua função puramente ideológica (MARINI; SPELLER, 1977, p. 6, grifo nosso)

Dessa relação indissociável entre o que se conformou no Brasil colonial e sua perversa condicionalidade escravista e oligárquica, assentada no monocultivo, forjou-se a produção político-econômica de uma independência formal de Portugal, sem destruir as raízes estruturais do colonialismo e do racismo. Tal condição, apresenta-se, sobre o controle da oligarquia agrária brasileira, no bojo da independência formal, em 1822, ao abrir novos processos de desenvolvimento, supostamente autônomos, mas renovando os vínculos de subordinação dos/das trabalhadores/as do campo, forçadas/os continuamente a migrarem para as nascentes cidades.

Ao longo do século XIX, sob as mudanças jurídicas e políticas decorrentes da propriedade privada da terra - Lei de terras 1850 (BRASIL, 1850) e dos processos correntes de uma alforria condicionada à posição de sem direitos, na qual os sujeitos escravizados foram postos em liberdade no plano mercantil de venda e controle sobre sua força de trabalho, passando de "[...] bom escravo a mau cidadão" (MOURA, p.16, 1977), nasce um novo contexto, mediado por velhas práticas racistas, patriarcais, neocoloniais (SOUZA, 2019; TRASPADINI, 2016).

A educação pública brasileira em geral, e superior em particular, retrata a história dos/das que, responsáveis pela edificação do desenvolvimento urbano e industrial no século XX, ficarão fora do sistema de educação superior. Esses/as trabalhadores/as, os/as "sem escola", "sem título" e com trabalho superexplorado, edificam o complexo urbano industrial, ao mesmo tempo em que ocupam terrenos irregulares nas cidades, formando os territórios populares. Condição inerente à própria lógica desigual do capital. É dessa relação entre o 
núcleo de trabalhadores fundadores do Brasil oligárquico, agrário e industrial, que a história da educação se apresenta como a história da exclusão formal.

Assim, o século XX repõe, na esteira da história do Brasil, a trajetória da exclusão educacional, do analfabetismo, e do restrito ensino técnico vinculado ao padrão de desenvolvimento dependente, para a abertura de portos, metalúrgicas, edificações etc., como o epicentro profissional de estradas e rodagens.

Sob a dominação ideológica imperialista-colonialista, internalizada pelos donos do poder, as ideias de ordem e progresso, tiveram ampla permeabilidade na consolidação do padrão ideológico de Nação. Ao tomar como modelo as nações que se desenvolveram da pilhagem das demais, e sem entender os seus males de origem (BOMFIM, 2008), as classes dominantes brasileiras, por meio do Estado, conciliaram a subordinação externa com a manutenção do seu status quo, ao mesmo tempo que buscavam justificar, na ideologia do desenvolvimento, tal malogro. Sob o colonialismo continuado, o racismo assume a forma da mais sofisticada arma ideológica de dominação, ou seja, o escravismo pleno (MOURA, 1994).

Constitui-se, na territorialidade colonial, a ideia força de que a presença de raças inferiores - negros e indígenas - era a causa do subdesenvolvimento nacional, condição coercitiva de produção de um consenso que permeou a organização social em geral na realidade brasileira. Nisso se assentou a institucionalidade da eugenia e do higienismo, no esforço de eliminação da "mancha negra”, sob a influência do racismo pseudocientífico (SCHWARCZ, 1993). O que significou a marginalização da população negra, não apenas do sistema educacional, mas em todos os setores mais significativos da sociedade cortada pelo sentido desigual de classe no acesso, permanência e direito à vida. Isto ocorria em consonância com a repressão policial e diversas formas de perseguição por parte das entidades eugênicas, as quais internalizam a perspectiva de desenvolvimento e humanidade desenhada desde o colonialismo (MOURA, 1994; COSTA, 2007).

A internalização colonialista do conhecimento, forjada desde os interesses centrais, erigiu as bases epistemológicas da universidade brasileira, cujos intelectuais reproduzirão largamente as ideias importadas, voltando-se pouco para a produção de um conhecimento próprio, ancorado nos interesses nacionais (BOMFIM, 2008; FERNANDES, 2006). 
O século XX, em âmbito global, foi mediado por revoluções e, também, por fascismos e ditaduras militares. Na América Latina e Caribe, sob as bases coercitivas das ditaduras militares, que encontramos as consolidações mais amplas de sistemas de educação. A educação militar retirou da escola o compromisso democrático com a realidade histórica das desigualdades estruturais. A moral e cívica edificou, entre 1964 a 1984, a violenta narrativa de uma pátria amada, idolatrada, que seguiu na mesma trilha da ordem e progresso presente no início do século, cujo salve era a ode ao desenvolvimento e modernização - à custa da marginalização de ampla maioria da classe trabalhadora. Assim, as reformas educacionais regidas pela batuta do governo militar ocorrem em um contexto de intensificação da dependência e, consequentemente, da superexploração. Isto, mediado pelo coercitivo processo de desaparecimento político e de torturas que, quando resistiam, eram obrigados a migrar forçosamente.

Para Marini e Speller (1977), tais reformas demarcam as características que definem um sentido mercantil de educação que, além de excludente da maioria, é também, um mecanismo de apropriação da riqueza socialmente produzida. Ao assumir uma forma expressamente mercantil, alheia às necessidades reais de grande parte dos/das que compõem a classe trabalhadora, refaz as rotas contínuas das ideias (neo)liberais, (neo)desenvolvimentistas no continente. Nas palavras dos autores:

O liberalismo em matéria educativa, praticado pelo regime militar, se manifesta: a) na entrega da educação superior à empresa privada, o que conduz à privatização do ensino e converte o ensino em negócio; b) liberação da matrícula, que somente encontra limites na capacidade do capital privado para criar oportunidades de ensino e na capacidade dos estudantes em aproveitá-las (entende-se aqui que essa capacidade é tanto intelectual como sócio-econômica); e c) na adequação entre a oferta e demanda da mão-de-obra técnica e profissional segundo o jogo do livre mercado (MARINI\&SPELLER, 1977, p. 13)

No entanto, não é somente o processo desigual do ensino "superior" que nos revela o caráter desigual da educação. Também o retrato da educação básica brasileira atual nos dá pistas sobre os elementos constitutivos de uma política educacional pública conduzida para a condição estrutural de superexploração. Segundo o Censo da Educação Básica (BRASIL, 2019; 2007): 
- São 180,6 mil escolas de educação básica (infantil, fundamental I e fundamental II), com quase 48 milhões de matrículas, sendo que $80 \%$ destas, estão na rede pública.

- 70\% do total de escolas atende a creches e ensino fundamental (109.6440), e tem-se apenas 28.860 escolas cobrindo o ensino médio. ${ }^{5}$

- Enquanto o ensino regular teve sua matrícula reduzida, o ensino profissional cresceu em 28,3\%, chegando a um total de 623 mil matrículas;

- A Educação de Jovens e Adultos, por sua vez, reduziu em média, 7,7\%, contando com 3,3 milhões de matrículas. Nesta modalidade, a reflexão que merece ênfase é a do número de estudantes com menos de 20 anos (mais de 1 milhão de jovens matriculados). As mulheres da EJA têm majoritariamente mais de 30 anos e estão no ensino fundamental I. Na EJA também a questão de raça e etnia prevalece, sendo pessoas pretas e pardas prevalecentes em $75,8 \%$ no ensino fundamental e 67,8\% no ensino médio. Miguel Arroyo reforça a tendência contemporânea da EJA como espaço de segregação, afirmação da exclusão, ausência de projeção de futuro, dada a realidade social concreta do mundo do trabalho (ARROYO, 2007\%).

- Quase 89\% das matrículas gerais estão efetuadas no perímetro urbano. Aqui merece destaque o fechamento de escolas do campo no período de 2002 a 2009, chegando à marca de 24.396 escolas a menos no período de 2002 a 2009 (BRASIL, 2019).

- A taxa de distorção idade-série é elevada tanto no fundamental como no ensino médio $23,4 \%$ e $26,2 \%$ respectivamente. É a denúncia real de que educação só é prioridade se a sobrevivência estiver mantida (ARROYO, 2007).

Quanto ao trabalho docente na educação básica, os dados também chamam a atenção, pois segundo o estudo do DIEESE (2014), Transformações recentes no perfil do docente das escolas estaduais e municipais de educação básica, evidencia-se a tônica

${ }^{5}$ Um subsídio e tanto para a reflexão das distorções series-idades e a intencional demarcação da educação profissional e Educação de Jovens e Adultos (EJA) como mecanismos substitutos da educação regular. Para esta reflexão ver ARROYO (2007).

${ }^{6}$ Nas palavras de Arroyo: "as velhas dicotomias, as velhas polaridades da nossa sociedade (e um dos pólos é o setor popular, os trabalhadores, e agora nem sequer trabalhadores) não estão se aproximando de uma configuração mais igualitária, ao contrário, estamos em tempos em que as velhas polaridades se distanciam e se configuram, cada vez mais, com marcas e traços mais específicos, mais diferentes, mais próprios. Mais distantes. A juventude popular está cada vez mais vulnerável, sem horizontes, em limitadas alternativas de liberdade” (ARROYO, 2007, p. 2). 
da precarização do trabalho na rede básica de educação. Vejamos:

- São 2,2 milhões de docentes em 2019.

- $32 \%$ trabalhava em uma jornada de 20 a 25 h semanais, enquanto $46,8 \%$ trabalhavam de 36 a mais de $40 \mathrm{~h}$ semanais.

- O rendimento salarial real médio do país é de $\mathrm{R} \$ 1.762,23$. As regiões Norte e Nordeste ficaram abaixo desta média, e Sudeste, Sul e Centro-Oeste, acima.

- A renda média dos professores estaduais e municipais em relação às demais profissões é $50 \%$ inferior na docência estadual e $83,8 \%$ inferior no plano municipal $^{7}$.

Analisemos também parte dos dados da educação "superior" (Censo da Educação Superior de 2018):

- Apenas 21,7\% dos jovens em idade universitária (de 18 a 24 anos) estavam matriculados em algum curso universitário em rede pública ou privada (BRASIL, 2019).

- Existem 2.448 instituições de ensino superior no país e, ao contrário da educação básica, majoritariamente pública, a supremacia no número de instituições e matrículas é do ensino privado. Dessa forma, na era do negócio da educação são: 296 instituições públicas e 2.152 instituições privadas. Das quase $11 \mathrm{mi}$ lhões de vagas ofertadas em 2017, apenas 823.843 eram públicas e 9.955.243, privadas.

- Quanto aos turnos de estudo, enquanto instituições públicas têm 64.5\% dos cursos ofertados pela manhã, as instituições privadas ofertam quase $70 \%$ de seu total à noite, situação que expõe que o ensino médio e superior são, ainda, uma realidade pouco concretizável para a classe trabalhadora (BRASIL, 2019).

- No plano do trabalho, são 381 mil docentes, distribuídos 45\% no setor público (171.231 professores) em comparação a 55\% no setor privado (210 mil), em 2017. Outro paradoxo: se a educação privada detém o maior número de matrículas do ensino superior, o número de docentes deveria ser muito maior, como já apontavam Marini e Speller em 1977.

Nesse sentido, mais uma vez a mercantilização da educação expõe os vínculos com a superexploração da força de trabalho no ensino superior priva-

${ }^{7}$ A distância entre esta remuneração e mínimo projetado como digno pelo DIEESE (de $\mathrm{R} \$ 4.420 .11$ em julho-2020) expressa as dimensões da superexploração, impondo a muitos profissionais que encontrem outras funções para complementar suas rendas, seja no setor educativo ou fora dele. 
do, assim como se verifica na rede básica de educação ${ }^{8}$. Isto, somado ao aumento contínuo da educação à distância, revela a faceta contemporânea de um modelo educativo que anuncia a morte dos encontros, da centralidade da educação pública e de qualidade e revela, nos ultrajantes movimentos de propaganda sobre a mercadoria educação, o "bom negócio" do financiamento educativo em diversas carreiras.

O retrato ampliado desse processo define, quando tratamos da educação superior, que chegar nela, fato bastante embarreirado se mantida idadesérie, é uma condição de classe e de raça no Brasil. E chegar, não significa permanecer e concluir. Houve nas primeiras décadas dos anos 2000, a explicitação desse movimento de contraditória e disputada, ampliação do acesso à educação superior em dois processos: 1) o Programa do Governo Federal de Apoio a Planos de Reestruturação e Expansão das Universidades Federais Brasileiras (REUNI) ${ }^{9}$ de 2007; e 2) a Lei 12.711/2012 (BRASIL, 2012) ${ }^{10}$, conhecida como "lei das cotas". Ambos têm a intenção de corrigir os desvios históricos sobre o acesso, o que, infelizmente, está longe de acontecer. Dentre as contradições, es-

${ }^{8} \mathrm{O}$ fato da desigualdade ser mais explícita na educação básica e superior privada, não significa dizer que a educação pública "superior" garanta direitos e qualidade no campo do trabalho. O que vale, de fato, é a totalidade da fotografia. E nesta, os/as trabalhadores/as da educação pública "superior" também se inserem em um articulado movimento desigual que compõe a média salaria geral do país. Entre os salários mais altos de quem tem longo tempo de carreira e os mais baixos, dos/das contratadas, tem-se um tensionamento para baixo dos rendimentos salariais, demarcados pela trajetória intensiva da superexploração da força de trabalho no Brasil (em intensidade, prolongamento das jornadas e, consequentemente, no aumento dos adoecimentos físicos e psíquicos). No entanto, essa diferença tem permitido, na propaganda das reformas conservadoras, criar um cenário de disputas e concorrências desleais para a realidade geral da educação, como se o/a professora do ensino superior tivesse condições de trabalho melhores.

${ }^{9}$ Foi instituído pelo Decreto Presidencial 6.096, de 24 de abril de 2007, com o objetivo de dar às instituições condições de expandir o acesso e garantir condições de permanência no Ensino Superior.

${ }^{10}$ De acordo com essa lei, as vagas reservadas às cotas $(50 \%$ do total de vagas da instituição) serão subdivididas - metade para estudantes de escolas públicas com renda familiar bruta igual ou inferior a um salário mínimo e meio per capita e metade para estudantes de escolas públicas com renda familiar superior a um salário mínimo. Em ambos os casos, também será levado em conta percentual mínimo correspondente ao da soma de pretos, pardos e indígenas no estado, de acordo com o último censo demográfico do Instituto Brasileiro de Geografia e Estatística (IBGE). O que não se efetiva, pois sendo a população de pretos e pardos no Brasil superior a $50 \%$ da população total, não se aplica uma reserva de vagas correspondente, pois impera a lógica da seletividade e não a da universalização do acesso. 
tão as parcas condições de permanência e conclusão dos cursos pelos matriculados, explicitando o afunilamento e seletividade na concretização da política. Nas universidades públicas, as políticas de permanência, restritas e precarizadas, desconsideram os critérios de entrada de pessoas negras e indígenas. Nesse sentido, dão passo às políticas afirmativas em geral, não havendo uma política de permanência específica para os estudantes cotistas.

Temos, assim, um processo de educação "superior" que contribui para destruir e apagar o sentido da política de ação afirmativa para o ingresso desses sujeitos nas universidades e para instituir uma seletividade meritocrática, vinculada à produtividade e desempenho estudantil, desembocando na mesma definição histórica da universidade pública brasileira como lugar para poucos, sem diversidade de classes, de raças e etnias, para a manutenção do domínio do capital sobre o trabalho. Já na rede particular, a permanência está condicionada ao pagamento das mensalidades, ao acesso ao financiamento estudantil e a condições de sobrevivência que, para grande parte dos estudantes-trabalhadores, significa a conciliação de longas jornadas de trabalho e estudos.

Os elementos destacados acima mostram que o "funil" que se apresenta no sistema educacional brasileiro expressa, não apenas, a histórica marginalização de grande parte da classe trabalhadora - em particular negros e indígenas - do acesso à educação, como, também, uma intencional padronização esquemática de saberes cristalizados na ordem hegemônica.

\section{DAS LUTAS SOCIAIS À EDUCAÇÃO FORMAL: A EDUCAÇÃO POPULAR ${ }^{11}$ COMO PRÁXIS, LUTA POR DIREITOS E JUSTIÇA.}

A história da luta social latino-americana nos remete a doloridos processos de violação-destruição culturais, vivenciados no período de invasão colonial e em suas respectivas derivações (BÁEZ, 2010). Ao longo de mais de cinco séculos, a produção de hegemonias foi realizada, não sem resistências contínuas, do Norte ao Sul do continente.

\footnotetext{
${ }^{11}$ Sobre o estudo da educação popular utilizaremos, ao longo de todo o texto, como referências diretas e indiretas: KOROL, C. (2016); PALUDO, C. (2015); JARA, O. (2019); TRASPADINI, R. (2016, 2018, 2006); DOS SANTOS, F. H. (2017); FREIRE, P. (1970); ALEJANDRO, M.; ROMERO, M. I.; VIDAL, J. (2012); BRANDÃO, C. (2007); CEPIS (2008).
} 
As derrotas, na esteira da luta de classes, dependeram, em muito, do teor das armas de morte massivas utilizadas contra os povos. Dessa destruição cultural violenta, entre o soterramento e ruptura concreta do que se encontrou, e a produção da resistência de forma reiterada, insistente, é que se erguem as experiências da educação popular na América Latina (RODRIGUEZ, 2013; KOROL, 2016).

$\mathrm{Na}$ química $^{12}$, os radicais livres, ao apresentarem o caráter ímpar dos elétrons no corpo, tendem a gerar oxidação, envelhecimento e morte celular/ molecular. Já na biologia, um agente externo encontra um hospedeiro para introjetar-se nele como corpo estranho, como no caso dos vírus, bactérias e parasitas em geral. Ao introjetarem-se em outros corpos, esses necessitam reagir, ou então, a doença progride e o corpo definha. Os intrometidos parasitas são hóspedes mal vindos à casa sem serem convidados.

$\mathrm{Na}$ antítese da química e da biologia, ou seja, no contraponto orgânico natural, encontra-se a produção social da luta pela libertação. A trajetória histórica do DNA da luta social na América Latina, aberta contra as mazelas do capital ao longo dos últimos 520 anos, expõe a radicalidade como premissa de sobrevivência, existência e resistência. Na sociologia da revanche, da construção social e política de libertação, a figura do radical livre apresenta-se como abrigo das resistências.

No plano social, o humano é o corpo-mente-sentido que hospeda, no processo par do encontro de classe, a consciência das resistências, ainda em meio à invasora e contínua tendência à colonialidade do ser, do saber e do poder (QUIJANO, 2000). Na estrada da colonização e do escravismo, a condição desumana a que parte do humano foi relegado, insiste, resiste e preside outros processos contrários à ordem da dominação - (MOURA, 2014; FREIRE, 1970; FALS BORDA, 2015).

Enquanto na química os radicais livres são uma ameaça orgânica ao bem estar físico dos seres vivos, na sociologia e na política latino-americanas, os sujeitos políticos, no ato de radicalidade de luta pela libertação, são corpos

\footnotetext{
${ }^{12} \mathrm{O}$ objetivo com esse exercício é meramente didático, mas toma em conta também que, na produção ontológica dos povos pré-colombianos, a relação entre ser, natureza e demais seres era muito mais harmoniosa que a separação ocorrida entre a ciência ocidental moderna. Basta analisar o calendário Maia, Asteca e a história de Ollantaytambo.
} 
em movimento de aprendizagem contínua, e em parte, reativos à trágica história do capital. A radicalidade é o anticorpo político e social ante a daninha história de opressão-escravização-superexploração. Na política se faz revanche ao parasita social, o capital, que se apodera da vida social, da força vital do trabalho e da natureza viva, como se tudo fosse mercadoria. É na coisificação desses corpos orgânicos - e na padronização violenta de uma América Latina ao serviço da Europa e dos EUA - que o parasita do capital tende a não reinar sozinho nos corpos que habita e enferma ao longo da história passada e presente no continente. A educação espelhará, e servirá de reflexo, os males dos séculos de dominação. Mas não sem disputas.

No Brasil, a presença da experiência como consciência e, posteriormente, da materialização das resistências e revoluções como transições possíveis, forjaram - na luta pela sobrevivência - os sujeitos radicais em busca de liberação, ante a opressão-escravização (1500-188) e posterior opressão-superexploração (1888-até o presente). Em todo o continente, a produção material da radicalidade é um ato educativo persistente. Radicalidade na manutenção de idiomas, de alimentações, de indumentárias, de culturas e tradições cujos sentidos de tempo, de vida, de ciência, de natureza, persistem ante à oxidação padronizadora do capital sobre o trabalho. Sobreviver mantendo a herança social das resistências, é um princípio da luta social latina. A subversão (FALS BORDA, 2015) e a libertação (FREIRE, 1970) forjam os temas-problemas da conscientização de classe em si e para si. Nos termos de Fals Borda, (2015, p. 288):

[...] la palabra subversión es una de aquellas que no se entienden sino para referirse a actos que van en contra de la sociedad, y por lo tanto designa algo inmoral. Sin embargo, llega el momento de preguntarse: ¿cuál es la realidad en que se mueve y justifica la llamada subversión? ¿Qué nos enseña sobre este particular la evidencia histórica? ¿Qué nos dicen los hechos actuales sobre los "subversores", "antisociales" y "enemigos de la sociedad"?

E segue o sociólogo colombiano (BORDA, 2015, p. 392)

[...] la subversión se descubre como una estrategia mayor y un proceso de cambio social y económico visto en toda su amplitud, y no sólo como una categoría para analizar la conducta divergente o los grupos margina- 
les producidos por la industrialización.

A Educação popular (EP) na América Latina se inscreve, na diversidade que compõe a luta de classes - indígena, quilombola e camponesa - na radicalidade da existência e manutenção do modo de ser próprio, em meio ao movimento destrutivo de reiteração da ordem mercantil capitalista. Do sujeito coletivo latino-americano, em seus múltiplos tons, a radicalidade subverte a ordem e gera, em meio às cotidianas coisificações (KOSIK, 1969; LOWY, 2009), uma desordem plena de si mesma, plena do popular que se educa na luta, para depois se educar na consciência histórica sobre suas raízes presentes no hoje. Por isso, reitera Freire (1970), que toda radicalização frente à ordem opressora - superexploradora - do capital, é um promissor legado de humanização emancipadora. Um antepor-se ao sectarismo a partir da vida cotidiana em pauta, em movimento contraditório entre o dever ser oprimido e o poder ser liberto, como destino produzido como inédito viável. Sustenta FREIRE (1970, p. 14):

O radical, comprometido com a libertação dos homens, não se deixa prender em "círculos de segurança", nos quais aprisione também a realidade. Tão mais radical, quanto mais se inscreve nesta realidade para, conhecendo-a melhor, melhor poder transformá-la. Não teme enfrentar, não teme ouvir, não teme o desvelamento do mundo. Não teme o encontro com o povo. Não teme o diálogo com ele, de que resulta o crescente saber de ambos. Não se sente dono do tempo, nem dono dos homens, nem libertador dos oprimidos. Com eles se compromete, dentro do tempo, para com eles lutar.

É no forjar radical de homens e mulheres livres que se apresenta a EP, ao mesmo tempo como método, conscientização, práxis, resistência e revolução. Cada um desses temas e seus sentidos depende, no tom da luta, da realidade concreta da luta de classes presente nos territórios e o teor a partir do qual seus inimigos tecem a coerção e o consenso para conter a rebeldia. Isto ocorreu em todo o período histórico que vai do escravismo-colonialismo, passa pelas guerras de independências e chega na formalização dos Estados Nacionais latino-americanos. Momento este em que a educação formal e a popular atritamse, mesclam-se, degeneram e regeneram o sentido do popular à luz do ato educativo opressor ou libertador. 
No Brasil, ao longo de todo o século XX, à medida em que o nacionaldesenvolvimentismo de Vargas se assentava no modelo urbano-industrial (1930-1945), em relação harmoniosa com o imperialismo estadunidense e seu bloqueio contra o perigo comunista, a história da educação formal correu em paralelo com as contestações, lutas, construções sociais. E desse movimento de apresentar-se como os visíveis, em uma sociedade que teima em desconsiderar sua existência, é que a EP se apresenta como brecha, contestação, movimento para além da exclusão. Herdeiros das lutas sociais pelo direito à vida, à terra e à outra concepção de humanidade - e suas relações criativas com o que entendem como o sentido de ser e natureza - camponeses, povos indígenas e quilombolas na América Latina e no Caribe, apresentaram seus processos de contestação à ordem. Ora com lutas abertas nas ruas, ora como guerra de guerrilha, em vida orgânica na selva, como viabilidade histórica contrária à tirania da superexploração e da exclusão.

A EP, no entanto, parece estar fora da educação formal como resultado da intencionalidade do capital contra e sobre o trabalho. No entanto, em essência, como revanche, está sempre dentro, como resultado histórico daqueles e daquelas que chegam ao ensino formal e carregam consigo suas histórias, trajetórias e feituras do ser, sentir e viver como popular. A educação formal insistirá em não os(as) tomar em conta. Elas/eles resistirão ao ataque, enquanto produzirem vida para além da escola.

A EP é o que reveste de sentido a luta social e de classes no Brasil ao longo do tempo. Ela é vinculada à experiência camponesa, mas também à urbana, sendo que nesta se destaca a atuação dos movimentos negros ao longo do tempo. Em ambas, atende as necessidades daqueles/as formalmente analfabetos/as ou com pouca escolaridade. No entanto, no plano real, a educação popular hospeda o DNA da resistência. Da luta por direitos - à moradia, à educação pública, à educação do campo, à terra, à alimentação, entre outras - à luta eleitoral, de disputa do institucional, passando pela luta pela sobrevivência no campo do trabalho formal ou informal, lido como legítimo e/ou legal ou não.

A EP se apresenta como o reverso do não poder dizer a palavra: Grita, dança, canta, cria culturas populares de contestação à ordem desigual. E dessa elaboração criativa, porque popular, irrompem novas personagens de históricos sujeitos em cena na luta social brasileira. A herança da educação popular é a luta 
social. E a luta social no caso brasileiro demarca a construção de uma nação e seus nacionalismos, que deixa de fora parte expressiva dos seus, como apontou Hobsbawm (1999).

\section{EXPERIÊNCIAS DE EDUCAÇÃO POPULAR NA PRÁXIS DOS MOVIMENTOS SOCIAIS BRASILEIROS}

A educação popular protagonizada pelos movimentos sociais camponeses $^{13}$, indígenas e negros no Brasil, está fora dos livros de história, de geografia e de literatura formais da educação básica e superior. Mas é inerente à vida cotidiana de milhões de trabalhadores/as que vivem de dar conta de sobreviver por dentro, ou por fora, da lógica formal assalariada.

As experiências dos movimentos negros brasileiros, demarcam a revanche daqueles/as cuja experiência histórica, assentada no racismo, perpassa pela ampla política de marginalização e dominação. No início do século XX, a experiência da Frente Negra Brasileira - (FNB, 1931-1937) - e a sua atuação no sentido da educação do povo negro no Brasil precisa ser lembrada como pioneira na educação popular. Em que pese as contradições da Frente e o caráter conservador dos seus principais dirigentes, em um momento em que o racismo pseudocientífico influenciava fortemente as instituições no país, ela teve uma incursão importante na reivindicação de igualdade e da inserção social da população negra, então recém saída da escravidão. A FNB criou uma escola exclusiva para negros e negras, e também teve iniciativas que extrapolavam a educação formal, com a criação de espaços comunitários de expressão artística e organização política etc. (BARBOSA, 1998).

A FBN foi encerrada em 1937 por Getúlio Vargas, mas no tempo em que esteve atuante, logrou concretizar projetos importantes com uma significativa filiação a nível nacional, cerca de duzentos mil inscritos. Além disso, criou diversas Frentes Negras estaduais, cujos projetos eram semelhantes, como a Frente Negra Pernambucana, fundada pelo poeta Solano Trindade (BARBOSA,

\footnotetext{
13 Para um debate sobre movimentos sociais na América Latina sugerimos: SVAMPA, Maristela. Protesta, Movimientos Sociales y Dimensiones de la acción colectiva en América Latina(2009). Disponível em: < http://www.maristellasvampa.net/archivos/ensavo57.pdf $>$. Acesso em : 5 set. 2020. E GHON, Maria da Gloria. Teoria dos movimentos sociais: paradigmas clássicos e contemporâneos. SP: Editora Loyola, 5a . edição, 2006.
} 
1998).

Assim como os demais movimentos sociais, os movimentos negros foram, ao longo da história do Brasil, perseguidos e interrompidos em seus objetivos e atuação. Mas o surgimento de novos, na esteira e no resgate da memóriahistória dos anteriores, desde Palmares, tem sido a resposta contra o autoritarismo e racismo que expressam a atuação política e ideológica das elites brasileiras. Todos ${ }^{14}$ eles terão a educação como pauta.

As propostas do Teatro Experimental do Negro - TEN - (19441961), criado por Abdias do Nascimento, iam no sentido de uma atuação política que cobrava do Estado o dever de garantir o direito à educação a todos os cidadãos. Pautava, assim, o "[...] ensino gratuito para todas as crianças brasileiras, admissão subvencionada de estudantes nas instituições de ensino secundários e universitário, de onde foram excluídos por causa de discriminação e da pobreza resultante de sua condição étnica" (NASCIMENTO, 1978, p. 193). De acordo com Gonçalves e Silva (2000, p. 149), há no TEM, um entendimento de que a educação e a cultura deveriam estar entrelaçadas. Sendo assim,

Entendem seus idealizadores que a escolarização, pura e simples, não bastaria para criar aquilo que Guerreiro Ramos chamou de "estímulos mentais apropriados à vida civil". Segundo ele, os negros desenvolveram um profundo sentimento de inferioridade cujas raízes estão na cultura brasileira. Para libertá-los desse sentimento não basta simplesmente escolarizá-los; seria preciso produzir uma radical revisão dos mapas culturais, que as elites e, por consequência, os currículos escolares, elaboraram sobre o povo brasileiro.

Essa perspectiva de atuação sobre a educação também se destaca no Movimento Negro Unificado (MNU), criado em 1978, e que tem um papel fundamental não apenas em pautar o acesso à educação pela população negra, mas em reivindicar que essa educação seja de fato emancipadora e não reprodutora da alienação, disputando, dentro das instâncias formais a condução de um processo de educação com ensino da história afro-brasileira, a execução de ações antirracistas, a denúncia e combate aos conteúdos racistas dos livros didáticos,

14 Além da FNB (1931), cabe destacar a Associação Cultural do Negro (ACN), criada em São Paulo em 1954; Instituto de Pesquisa e Cultura Negra (IPCN), constituído no Rio de Janeiro em 1975; e o Movimento Negro Unificado Contra a Discriminação Racial (MNU) em 1978. 
etc. (GONÇALVES; SILVA, 2000). Tal movimento teve, também, um papel fundamental na defesa das ações afirmativas para inserção de negros/as nas universidades públicas, implementadas recentemente.

A luta dos movimentos negros organizados pelo direito à educação formal, para que o Estado cumpra o seu dever de garanti-la, esteve sempre no centro dessas organizações. Entender a perspectiva da EP enquanto parte da luta política pelo acesso ao direito social, pelo direcionamento da educação que se quer - antirracista, anticolonialista, para a desalienação e emancipação - pos sibilita entendermos que, mesmo quando aponta para a inserção formal e institucional, o processo é popular. Reivindica e se faz pela história e resistência daquelas e daqueles excluídos do formal/institucional. Atualmente, isso se expressa de maneira contundente nos cursinhos populares preparatórios para o vestibular. ${ }^{15}$ Face à ausência de universalização do acesso à educação, estas estratégias demarcam a organização social e comunitária para que jovens negros/as, e moradores/as das amplas periferias de todo o Brasil, tenham chances maiores de ingressar na Universidade. Mas eles são, sobretudo, espaços de formação e construção de perspectivas calcados também nas experiências e necessidades desses sujeitos, e nisso se explicita o seu caráter popular.

A trajetória da luta pela educação, por parte dos movimentos negros ao longo da história do Brasil, explicita o processo de acúmulo e amadurecimento no qual o próprio sentido educativo, vai se ampliando junto à crítica da sociabilidade que cria a exclusão e o racismo. O sujeito principal da educação popular é coletivo. Apresenta-se, na consciência em si, em um contínuo processo de formação de consciência para si. Enquanto sujeito coletivo, educa-se enquanto luta. Essa razão dialética explicita que sua pauta não é somente a do direito, ainda que o reivindique, e sim a da justiça. Como tal, há a compreensão de que a luta pontual necessita afinar-se com um outro projeto societário em meio à compressão violenta da ordem vigente.

\footnotetext{
${ }^{15}$ Destes, podemos citar a experiência do EDUCAFRO e da UNEafro Brasil- União de Núcleos de Educação Popular para Negras/os e Classe Trabalhadora. Ambos com ações políticas e sociais que integram cultura, educação, organização comunitária etc., na luta contra a exclusão, a exploração e o racismo. Ver mais em: < http://www.educafro.org.br/site/conheca-educafro/> e

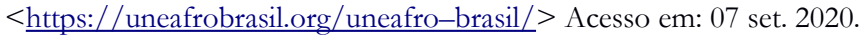


Ao menos para parte dos movimentos sociais contemporâneos - que não se confundem com o Terceiro Setor protagonizado pelas ONG's, dado que sua herança é a da luta pela sobrevivência, essa perspectiva de atuação social comprometida com a transformação é a base na qual se finca a reivindicação e desenvolvimento de concepções de educação para além da manutenção e/ou inserção na ordem estabelecida.

Nesse sentido, podemos elencar também as experiências de educação popular que se desdobram da luta pela terra, cujo processo educativo é da práxis reflexiva e revolucionária (VÁZQUEZ, 2007), como as do Movimento dos Trabalhadores Rurais Sem Terra do Brasil (MST), do Movimento dos Pequenos Agricultores (MPA) e do Movimento de Mulheres Camponesas (MMC). Estes expressam uma práxis que envolve uma reflexão enquanto atuam e uma atuação refletida.

Portanto, suas pautas, como a luta pela terra, em plena expansão da fronteira agrícola do agronegócio, ganham, ao longo do tempo, a necessária apreensão de um projeto democrático, soberano e popular. E se conectam com as heranças da mesma ordem existentes em Canudos (Bahia, 1896-1897); Contestado (Santa Catarina e Paraná, 1912-1916); Porecatu (Paraná, 1946-1951); dentre outros. Também das lutas organizadas sem grandes movimentos sociais consolidados, mas com intensa apreensão sobre o vivido: as quebradoras de coco do Tocantins; as mães na luta pela justiça por seus filhos desaparecidos; os movimentos que brotam das ruínas da exclusão, os sem direito à vida mercantilizada.

As experiências recentes de educação, cultura e produção de vida, remanescentes do século XX, originadas para e desde o popular, como as protagonizadas pelos movimentos sociais - como TEN, MNU, MST, MMC e MPA -, nos brindam bons exemplos da recuperação da ontologia do ser social para além da forma mercadoria na América Latina. Vejamos alguns exemplos da centralidade da luta social na educação popular:

Entre 2018-2019, a soma da produção de 362 famílias de 15 assentamentos do MST no sul do país, chegou à cifra de 16 mil toneladas de arroz orgânico. Isto, somado à mais de 22 mil sacas de sementes limpas de venenos. A maior produção de arroz orgânico da América Latina e o Caribe, em apenas 3.456 hectares, mesclados com outros modelos agrícolas vinculados à educação 
agroecológica (RAUBER; MST, 2019).

Um integrante do MST do setor de produção, Zarref (2019), relata que a agroecologia mais do que uma técnica presente somente nos espaços com forte escala de produção vinculada ao processo produtivo, de organização coletiva, das cooperativas agrícolas: este modelo abarca uma concepção de desenvolvimento que envolve todas as esferas da vida. A agroecologia é um modo de organização da vida familiar e coletiva, em que a produção se harmoniza com outro jeito de conceber a natureza e as relações sociais vinculadas a ela. É, portanto, uma matriz de produção em transição, dos conservadores processos à renovadas aprendizagens educativas no âmbito dos acampamentos e assentamentos do MST (ZARREF; MST, 2019).

$\mathrm{Na}$ agroecologia, a educação popular pulsa como movimento de negação da ordem mercantil via uma práxis contestatária e de reflorescimento tanto do humano, como deste em sua relação com a natureza. Via educação popular, a agroecologia tensiona na via de um outro sentido técnico de educação formal. Nas escolas, nos cursos de formação e nas aprendizagens de socialização entre diferentes organizações, as trocas explicitam um valor de uso muito superior à ideia força mercantil do valor de troca.

Outro importante exemplo da educação popular, que reorienta nas disputas cotidianas como práxis o sentido de educação formal, para quê e para quem, está a experiência do Movimento de Mulheres Camponesas do Brasil (MMC). Tal experiência engloba a produção de alimentos, o cultivo de sementes e o combate de todo tipo de ação cotidiana referenciada no machismo, cujas raízes remontam à força do patriarcado. $\mathrm{Na}$ afirmação de princípios consolidadores de novos valores - na consigna de Che Guevara e de Alexandra Kollontai e a necessidade do nascimento da nova mulher e do novo homem - as mulheres camponesas aprendem, enquanto dialogam, estudam e produzem vida cotidiana, que a história do papel da mulher na sociedade é muito maior do que a subjugação efetivada na lógica da colonização em diante.

Historicidade, relacionamentos e aprendizagens coletivas, tornam-se o centro de uma produção de alimentos arraigada em outras dinâmicas da divisão social do trabalho na família e na terra. O mundo camponês, assim como o cotidiano das cidades, está impregnado de violências objetivas e subjetivas orientadas ao condicionamento da mulher como refém da autoridade e/ou autorização 
dos homens, sejam eles patrões ou maridos. A mudança na narrativa, patriarcal, de meu homem, para a construção de um sentido comum de companheirismo, apresenta-se no MMC como práxis real cotidiana. Aprender a dizer, aprender a fazer, aprender a reviver e ressignificar os encontros. No documento base de fundamentação de sua práxis (2007), encontramos:

A missão é a libertação das mulheres trabalhadoras de qualquer tipo de opressão e discriminação. Isso se concretiza nas lutas, na organização, na formação e na implementação de experiências de resistência popular, onde as mulheres sejam protagonistas de sua história. Lutamos por uma sociedade baseada em novas relações sociais entre os seres humanos e deles com a natureza (MMC, 2007, p. 1).

Outro destaque similar ao do MST e do MMC é o do Movimento dos Pequenos Agricultores. No livro "Trincheiras da resistência camponesa sob o pacto de poder do agronegócio" (2017) Frei Sergio Görgen, expõe que a luta dos movimentos no campo é em um duplo sentido: 1) contra as políticas venenosas do agronegócio; 2) a favor de um novo modelo de desenvolvimento assentado no plano camponês, cujas raízes históricas são as das resistências latino-americanas. Nas palavras do Frei GÖRGEN (2017, p. 16, grifo nosso): “O $\mathrm{MPA}$, assim como um rio, tem muitas nascentes, surgiu em vários lugares do país na mesma época e pelas mesmas razões, construído pela força da luta, pela pressão da base, pela vontade da militância e para mudar a situação vivida pela classe camponesa". É do fazer-se na luta, repensar-se a partir da aprendizagem explicitada na cotidianidade de defesa de um outro sentido de humano, de natureza e de produção, que a educação popular que brota do MPA revigora o sentido de que há formalização da experiência ainda quando, institucionalmente, não se reconheça.

$\mathrm{Na}$ aprendizagem manifesta na cultura popular camponesa, os desafios que se abrem, na produção do novo em meio ao velho modo hegemônico que se espraia de forma onipotente são diversos: a) produção diversificada; b) produção para o autoconsumo; c) produção com baixo custo; d) produção da própria energia; e) o valor do trabalho; f) produção dos princípios da agroecologia (GÖRGEN, 2017).

Juntas, estas experiências demarcadoras do sentido de latino-americani- 
dade forjado na luta pela terra ou pela dignidade - de uma trajetória histórica de luta pela terra no Brasil -, reforçam a partir de um processo cotidiano de aprender a aprender (FREIRE, 1987), que a educação popular ganha expressão e comunicação a partir do movimento dos corpos em ação reconstrutiva do DNA social latino-americano e caribenho. Mais do que a idealização destas experiências, o que narramos é a possibilidade aberta da revanche, ainda quando isto pareça ser impossível. Das contradições do modo de produção ancorado na propriedade privada, nascem movimentos que se apresenta, ao longo do tempo, como sua antítese. Ora mais evidente, ora menos, a depender da correlação de forças presente entre o viver-sobreviver, e o viver-bem viver.

No desenho histórico da trajetória de lutas - ao longo dos séculos XV em diante no Brasil -, também se apresentam sujeitos, religiosos e/ou militantes sociais, que se colocaram a serviço das experiências populares. Irmã Doroth $^{16}$, Padre Josimo ${ }^{17}$ e Padre Gabriel ${ }^{18}$, por exemplo, pagaram com suas próprias vidas por defenderem a luta social. Dom Pedro Casaldáglia ${ }^{19}$ teve uma vida larga de luta ao longo do velho Chico. ${ }^{20}$ Esteve ao lado, aprendeu junto, enquanto caminhou defendendo a saga das marchas camponesas e indígenas da região. Assim também o foi com Chico Mendes ${ }^{21}$ e demais defensores e defensoras das lutas sociais e da vida para além de sua apropriação privada para o giro do capital.

\footnotetext{
${ }^{16}$ Dorothy Mae Stang, irmã Doroth, membro da CPT, foi assassinada em uma emboscada em 2005 com cinco tiros a queima roupa, em Anapu, Pará.

${ }^{17}$ Padre Josimo Morais Tavares, conhecido como o caminhante, padre, negro de chinelos surrados e boa prosa, também integrante da CPT, foi assassinado em 1986 em Tocantins, Araguaia. Assassinado a queima roupa com 2 tiros.

${ }^{18}$ Padre Gabriel Felix Roger Maier, morto em Cariacica-ES, em 1989, com crime prescrito após mais de 30 anos sem punição.

${ }^{19} \mathrm{Um}$ dos mais importantes nomes da defesa dos povos amazônicos e dos sistemas ambientais, morreu em 2020 após uma vida inteira entregue ao trabalho social. Único entre os aqui citados que resistiu com vida às contínuas barbaridades dos latifundiários, violências concretas com ameaças veladas ou explícitas.

${ }^{20}$ Rio São Francisco que, como muitos foi agredido pela leitura unívoca e onipotente do desenvolvimento para a lógica de produção e reprodução do capital, tendo como consequência alagamentos, mortes de vidas e de habitats tanto de humanos, como de uma diversidade grande de espécies. A transposição com o nome político institucional de "Projeto de Integração do Rio São Francisco com Bacias Hidrográficas do Nordeste Setentrional" narra a saga do desenvolvimento desigual brasileiro.

${ }^{21}$ Grande referência da defesa dos povos da floresta e da natureza, Chico Mendes foi mais uma vítima da luta pela terra no Brasil, assassinado nos fundos de sua casa, em 1988.
} 
A EP floresce dessas sementes germinadas na ação contestatária à violência da ordem do capital. Seja nas escolas de formação sindicais, ou nos cursos de trabalho de base das Comunidades Eclesiais de Base (BETTO, s/d), a EP se apresenta como voz-ação dos que reagem à ação insistente de morte em vida que paira sobre os territórios que são forçados a migrar continuamente.

\section{CONSIDERAÇÕES NADA FINAIS}

O título do presente texto apresenta uma síntese da relação contraditória e complementar que há entre educação popular e educação formal no Brasil. Ancoradas na tradição marxista entendemos que a radicalidade é um ingrediente vital da luta social no passado e no presente. Nos termos de Marx (2010, p. 151-152):

A arma da crítica não pode, é claro, substituir a crítica da arma, o poder material tem de ser derrubado pelo poder material, mas a teoria também se torna força material quando se apodera das massas. A teoria é capaz de se apoderar das massas tão logo demonstra ad hominem, e demonstra ad hominem tão logo se torna radical. Ser radical é agarrar a coisa pela raiz. Mas a raiz, para o homem, é o próprio homem. A prova evidente do radicalismo da teoria alemã, portanto, de sua energia prática, é o fato de ela partir da superação positiva da religião. A crítica da religião tem seu fim com a doutrina de que o homem é o ser supremo para o homem, portanto, com o imperativo categórico de subverter todas as relações em que o homem é um ser humilhado, escravizado, abandonado, desprezível. Relações que não podem ser mais bem retratadas do que pela exclamação de um francês acerca de um projeto de imposto sobre cães: "Pobres cães! Querem vos tratar como homens!"

$\mathrm{Na}$ radicalidade das resistências, buscamos situar o debate da educação popular e da sua importância, na trajetória histórica da luta de classes na América Latina. Ao entendê-la como práxis radical, em meio às contradições inerentes à estrutura capitalista dependente, acenamos no próprio movimentar dos/ das explorados/das e dominados/as contra o imperialismo-colonialismo, que se forja a riqueza da educação popular. Mais do que alfabetizar, letrar, suprir as lacunas deixadas pela excludente educação formal, a EP se faz viva como parte integrante do processo de luta por igualdade, justiça e emancipação. 
A educação popular é um movimento contínuo de construção-reconstrução em meio às mais desumanas condições de destruição ambiental e ontológica. No fluxo-refluxo da vida, o vento, o fogo, a água e o ar, dão o tom da resistência. $\mathrm{Na}$ força dos quatro elementos, a EP ora burla, ora fere, o sentido da educação formal no capitalismo dependente. E no movimento contínuo de dispersão-difusão do seu poder ser, os/as protagonistas da EP não aceitam a rota de desenvolvimento excludente como via de mão única que os/as condena à margem, à morte em vida.

Enraizado na EP, o popular expõe sua cultura de luta, e provoca a educação formal sobre a função do saber em meio à ordem da precarização do trabalho. Insiste, na resistência, em expor as veias abertas pela alienação colonialista.

Os sujeitos, suas territorialidades produzidas na conformação do popular (como cultura, educação e território), tensionam a ordem do capital, com a desordem da educação popular. Nas bordas dos oceanos Atlântico e Pacífico, movimentos indígenas, negros/as, camponeses e sem tetos, sem pão, dão a tônica da maré de lutas. No vai e vem das ondas, as lutas de lá (Norte), aprendem com as resistências de cá (Sul) e juntas dimensionam o teor tectônico do popular latino-americano. Território vulcânico, de lavas e rochas sedimentadas pelo movimento das placas, a EP forja, no presente, a aliança histórica com o passado de luta. E deixa aberta a aprendizagem sobre o porvir à luz do real vivido.

O retrato da educação formal no Brasil, evidenciado pelos dados, mostra o abismo entre a grande maioria da classe trabalhadora, em particular sua parcela mais pauperizada, negros/as e indígenas, e o acesso, permanência e conclusão restritos. A negação do acesso à educação se define em concomitância à consensual e coercitiva ordem colonialista e repressora (LEHER, 2016). Esta, erige-se como um projeto que já nasce destruído, como afirmou Darcy Ribeiro. As muitas reformas, ocorridas ao longo do recente século XXI, apenas acentuaram a destruição e a afirmação do sentido mercantil, de domínio ideológico do capital, sobre os necessários processos de emancipação e libertação populares.

Ao trazermos algumas experiências de educação popular no Brasil do século XX e XXI, evidenciamos que, de diferentes modos, os sujeitos coletivos organizados, pleiteiam, historicamente, processos educacionais contrários aos 
interesses dominantes. Assim, o apagamento da memória-história das suas lutas e a repressão do seu movimento de contestação refletem na invisibilidade, no âmbito da educação formal, da sua presença social e das disputas que lançam sobre as instituições, bem como no silenciamento e reiteradas tentativas de exclusão daqueles e daquelas que trazem consigo o DNA da luta e resistência nas cores latinas.

A inserção no formal/institucional gera incômodos ao ordenamento "normal", excludente e elitista, das escolas públicas em seus diferentes graus de ensino. Tanto estudantes - que com a sua presença impõem a experiência e resistência, às misérias da vida superexplorada e das violências cotidianas, reivindicando saberes que deem conta de explicar e expressar a suas vidas -, como professores/as comprometidos/as com uma perspectiva crítica, articulada com as lutas dos povos e oriundos/as das parcelas mais pauperizadas da classe trabalhadora, expressam a dinâmica desse incômodo e abrem conflitos e disputas de grande importância para a construção de outra perspectiva de educação. Desta condicionalidade brota a EP como revanche histórica, insubordinação, resistência e construção de alternativas à miséria material-espiritual da sociedade burguesa no capitalismo dependente. A educação popular, referenciada na história, projeta a memória de luta de nossos povos.

\section{REFERÊNCIAS}

ALEJANDRO, M.; ROMERO, M. I.; VIDAL, J. ¿Que es la educación popular? Havana: Editorial Caminos, 2012.

AMARAL, M. Verbete da superxploração do trabalho. In LUEDEMANN, C.; YOSHIDA, M. M. C. (Org.). Ruy Mauro Marini e a dialética da dependência. São Paulo: Expressão popular, 2014.

. Balanço da EJA: o que mudou nos modos de vida dos jovens-adultos populares? SP: Revista de Educação de Jovens e Adultos, v. 1, n. 0, p. 1 108, ago. 2007.

BÁEZ, F. A história da destruição cultural da América Latina. São Paulo: Vova Fronteira, 2010. 
BARBOSA, M. Frente Negra Brasileira: depoimentos / entrevistas e textos. São Paulo: Quilombo hoje, 1998.

BETTTO, F. Desafios da educação popular: as esferas sociais e os novos paradigmas da educação popular. Piauí: Corpo de Assessoria Jurídica Estudantil, s/ data. Disponível em: < https://www.google.com/amp/s/document.onl/amp/ documents/desafios-da-educacao-popular-frei-betto.html $>$. Acesso em: 7 set. 2020.

BOMFIM, M. América Latina: males de origem. Livro digital: Biblioteca Virtual de Ciências Humanas do Centro Edelstein de Pesquisas Sociais, 2008. Disponível em: <http://www.do.ufgd.edu.br/mariojunior/arquivos/

BOMFIM A America_Latina_Males de origem.pdf $>$. Acesso em: 05 set. 2020.

BRANDÃO, C. R. O que é educação. São Paulo: Brasiliense, 2007.

BRASIL. Lei de terras. RJ: Governo Federal, 1850. Disponível em: $<\underline{\text { http:// }}$ www.planalto.gov.br/ccivil 03/Leis/L0601-1850.htm>. Acesso em 10 de julho 2020.

. Lei 12.711. DF: Governo Federal, 2012. Disponível em: < $\underline{\text { http:// }}$ www.planalto.gov.br/CCIVIL_03/Ato2011-2014/2012/Lei/L12711.htm>. Acesso em: 5 ago. 2020.

. Instituto Nacional de Estudos e Pesquisas Educacionais Anísio Teixeira (Inep). Panorama da educação do campo. Brasília: INEP/MEC, 2007. Disponível em: <file://C:/Users/robertatraspadini/Downloads/Panorama $\% 20 \mathrm{da} \% 20$ Educa $\%$ C3\%A7\%C3\%A3o\%20do\%20Campo.pdf $>$. Acesso em: 29 ago. 2020 .

. Instituto Nacional de Estudos e Pesquisas Educacionais Anísio Tei-

xeira (Inep). Censo da educação superior. Brasília: INEP/MEC (Resumo técnico), 2018. Disponível em: < http://portal.inep.gov.br/informacao-da-publicacao/-/asset publisher/6JYIsGMAMkW1/document/id/6769555>. Acesso em: 29 ago. 2020.

BRASIL. Instituto Nacional de Estudos e Pesquisas Educacionais Anísio Teixeira (Inep). Censo da Educação Superior 2018: notas estatísticas. Brasília, 
2019. Disponível em: < $\underline{\text { http://portal.inep.gov.br/artigo/_/asset publisher/ }}$ B4AQV9zFY7Bv/content/dados-finais-do-censo-escolar-2018-sao-publicados-no-diario-oficial-da-uniao/21206 > Acesso em: 29 de ago. 2020.

. Instituto Nacional de Estudos e Pesquisas Educacionais Anísio Teixeira (Inep). Censo da educação básica. Brasília: INEP/MEC (Resumo técnico), 2019. Disponível em: < http://portal.inep.gov.br/documents/186968/0/ Notas + Estat $\%$ C3 $\%$ ADsticas + Censo + da + Educa $\% C 3 \%$ A $7 \% \mathrm{C} 3 \% \mathrm{~A} 3 \mathrm{O}+\mathrm{B}$ $\% \mathrm{C} 3 \% \mathrm{~A} 1 \mathrm{sica}+2019 / 43 \mathrm{bf} 4 \mathrm{c} 5 \mathrm{~b}-\mathrm{b} 478-4 \mathrm{c} 5 \mathrm{~d}-\mathrm{ae} 17-\mathrm{d} 55 \mathrm{ced} 4 \mathrm{c} 37 \mathrm{~d}$ ?version $=1.0>$. Acesso em: 27 ago. 2020.

CEPIS. Educação Popular e Movimento Popular. São Paulo: CEPIS, 2008. COSTA, J. F. História da Psiquiatria no Brasil. Rio de Janeiro: Garamond, 2007.

CUEVA, A. O desenvolvimento do capitalismo na América Latina. São Paulo: Global Ed. 1983.

DIEESE. Transformações recentes no perfil do docente das escolas estaduais e municipais de educação básica. Uma análise a partir dos dados da Pnad. SP: Nota técnica digital n141, 2014. Disponível em: < $\underline{\text { https://www.diee- }}$ se.org.br/notatecnica/2014/notaTec141DocentesPnadvf.pdf Acesso em 31-820>. Acesso em: 15 de ago. 2020.

DOS SANTOS, T. Imperialismo y dependencia. México: Editora Era, 1978.

DOS SANTOS, F. H. Considerações sobre a educação popular e o serviço social: um diálogo com os pressupostos freirianos. Revista de Educação, Rio de Janeiro, ano 4, n. 7, p. 303-325, jul./dez. 2017.

FALS BORDA, O. Una sociología sentipensante para América Latina.

In:_. Antología y presentación, Víctor Manuel Moncayo. México: Siglo XXI Editores, 2015.

FERNANDES, F. Capitalismo dependente e classes sociais na América Latina. 3. ed. Rio de Janeiro: Zahar, 1983.

A revolução Burguesa no Brasil: ensaio de interpretação sociológica. 5. ed. São Paulo: Globo, 2006. 
FREIRE, P. Pedagogia do oprimido. Rio de Janeiro: Paz e Terra, 1970.

. Fe y pueblo. Entrevista concedida a Revista Boliviana. Fé y pueblo, año IV, n. 16 y 17, 1987.

FRIGOTTO, G.; CIAVATTA, M. A educação no labirinto do capital. São Paulo: Outras expressões, 2016.

GALEANO, E. As veias abertas da América Latina. Rio de Janeiro: Paz e Terra, 1971.

GÖRGEN, F. S. A. Trincheiras da resistência camponesa. Sob o pacto de poder do agronegócio. Rio Grande do Sul: Instituto Padre Josimo, 2017.

GONCALVES, L. A. O.; SILVA, P. B. G. Movimento negro e educação. Revista Brasileira de Educação, , n. 15, set./out./nov./dez. 2000. Disponível em:

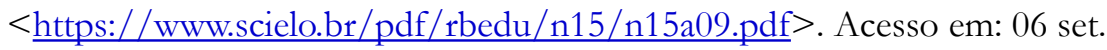
2020 .

HOBSBAWM, E. Nações e nacionalismo desde 1780. Rio de Janeiro: Paz e Terra, 1990.

INSTITUTO BRASILEIRO DE GEOGRAFIA E ESTATÍSTICA (IBGE). Metadados. DF: Ministério do trabalho, 2020. Disponível em: $<\underline{\text { https://ces.ib- }}$ ge.gov.br/base-de-dados/metadados/mte/relacao-anual-de-informacoes-sociais-rais $>$. Acesso em 5 de ag. 2020.

INSTITUTO PAULO MONTENEGRO. Indicador de analfabetismo funcional - Brasil, SP: INAF, 2018. Disponível em: < https://drive.google.com/ file/d/1ez-6jrlrRRUm9J3MkwxEUffltjCTEI6/view>. Acesso em: 5 ago. 2020 .

JARA, O. Educación popular, contexto latino-americano y el legado de Paulo Freire. Educ. rev., Belo Horizonte, n. 4, vol. 35, pag. 12 a 37, set/ago. 2019. - Jara O. A educação popular latino-americana, história e fundamentos éticos, políticos e pedagógicos. São Paulo: Alforja, Ação Educativa, Enfoc-Contag, CEAAL; 2020.

KOROL, C. La educación popular em clave de debate. Argentina: Otras 
Voces em Educación, 2016. Disponível em: $<$ http://otrasvoceseneducacion.org/archivos/84631\&gt>. Acesso em: 5 set. 2020.

KOSIK, K. Dialética do Concreto. Rio de Janeiro: Paz e Terra, 1969.

LEHER, R. Conjuntura, luta de classes e educação. Entrevista concedida à Revista Germinal. Marxismo e Educação em Debate, Salvador, v. 8, n. 1, p. 180-186, jun. 2016. Disponível em: $<\underline{\text { https://portalseer.ufba.br/index.php/re- }}$ vistagerminal/article/view/17368/11687>. Acesso em: 31 ago. 2020.

LEI DE TERRAS. RJ: Governo Federal, 1850. Disponível em: $<\underline{\text { http://www.- }}$ planalto.gov.br/ccivil 03/Leis/L0601-1850.htm>. Acesso em 10 de julho 2020.

LEI 12.711. DF: Governo Federal, 2012. Disponível em: $<\underline{\text { http: } / / \text { www.planal- }}$ to.gov.br/CCIVIL 03/Ato2011-2014/2012/Lei/L12711.htm >. Acesso em 5 de ag. 2020.

LOWY, M. Revoluções. São Paulo: Boitempo, 2009.

MARINI, R. M. Dialética da dependência. In: TRASPADINI, R.; STÉDILE, J. P. Ruy Mauro Marini vida e obra. São Paulo: Expressão popular, 2011.

MARINI, R. M.; SPELLER, P. A universidade brasileira. Revista de Educación Superior, México, v. VI, n. 2 (22), abr./jun. 1977. Disponível em:

$<$ http://www.marini-escritos.unam.mx/053 universidad brasil.html $>$. Acesso em: 5 ago. 2020.

MARX, K. Crítica à filosofia do direito de Hegel. São Paulo: Boitempo, 2010.

MOVIMENTO DE MULHERES CAMPONESAS. Organizar a base, produzir alimentos saudáveis, construir caminhos de libertação. SP: MMC, 2007. Disponível em: $<$ http://www.mmcbrasil.com.br/site/materiais/download/cartilha tbase2007.pdf>. Acesso em: 02 ago. 2020.

MOURA, C. O negro: de bom escravo a mau cidadão? São Paulo: Conquista, 1977.

. O racismo como arma ideológica de dominação. Revista Princípios. 
SP: n. 34, Ago/set/out, pág. 28- 38, 1994.

NASCIMENTO, A. Genocídio do negro brasileiro: processo de um racismo mascarado. Rio de Janeiro: Paz e Terra, 1978.

PEREZ, E. Que es educación popular hoy? Buenos Aires: Pañuelos Rebeldes, 2016.

PALUDO, C. Educação Popular como resistência e emancipação humana. Cad. CEDES, online, v. 35, n. 96, p. 219-238, maio/ago. 2015.

QUIJANO, A. Colonialidad del poder, eurocentrismo y América Latina. Argentina: Siglo XXI editores, 2000.

SOUZA, C. L. S. de. Terra, trabalho e racismo: veias abertas de uma análise histórico-estrutural no Brasil. 2019. 245 pg. Tese (Doutorado em Serviço Social) - Programa de Pós Graduação em Serviço Social, Centro Socioeconômico, Universidade Federal de Santa Catarina, Florianópolis, 2019.

SCHWARCZ, L. M. O espetáculo das raças: cientistas, instituições e questão racial no Brasil: 1870-1930. São Paulo: Companhia das Letras, 1993.

RAUBER, M. Conheça a maior produção de arroz orgânico da América Latina, do MST. SP: MST, 2019. Disponível em: < https://mst.org.br/2019/03/14/conheca-a-maior-producao-de-arroz-organico-da-america-latina-do-mst $/>$. Acesso em: 30 ago. 2020.

RODRIGUEZ, L. Educación popular en la historia reciente de Argentina y América Latina. Buenos Aires: APEAAL, 2013.

TRASPADINI, R. América Latina: entre el mundo del trabajo y el mundo del capital. In: CERUTTI, H.; MONDRAGÓN, M. (orgs). Resistencia Popular y Ciudadanía Restringida: Política, economía y sociedad en América latina y Caribe. México: UNAM, 2006.

Questão agrária, imperialismo e dependência na América Latina: a trajetória do MST entre novas-velhas encruzilhadas. 2016. 356 p. Tese (Doutorado em Educação, Faculdade de Educação ) - Universidade Federal de Minas Gerais, Belo Horizonte, 2016. 
A dialética da dependência contemporânea: a educação como mercadoria. SC: REBELA, online, v. 8, n. 1. jan./abr. 2018.

VÁZQUEZ, A. S. Filosofia da práxis. São Paulo: Expressão Popular, 2007.

ZARREF, L. A agroecologia e o MST. SP: MST, 2019. Disponível em:

$<$ https://mst.org.br/2018/10/24/agroecologia-e-o-mst/>. Acesso em: 01 set. 2020 . 